\title{
PEMANFAATAN MEDIA VLOGGING UNTUK PENGEMBANGAN PEMASARAN DESA WISATA KABUPATEN LEBAK (SAWARNAH DAN BAYAH)
}

\author{
Yoyoh Hereyah ${ }^{1}$, Cheryl Kanza AW ${ }^{2}$ \\ ${ }^{1}$ Universitas Mercubuana Jakarta \\ ${ }^{2}$ Universitas Gadjah Mada \\ Yoyoh.hereyah@mercubuana.ac.id, cherylkanza@mail.ugm.ac.id
}

\begin{abstract}
Abstrak
Akses internet yang luas dan tidak terbatas sering dimanfaatkan untuk berbagai hal bisa untuk bermain sosial media, game online, belanja online, dan internet juga bisa dimanfaatkan untuk memberikan informasi, menghasilkan keuntungan seperti produk yang dikenal khalayak luas baik produk makanan, minuman, wisata atau yang lainnya. Kampung tematik adalah kampung yang disokong oleh pemerintah yang bertujuan untuk membenahi semua wilayah secara masif dan tepat sasaran dengan melakukan beberapa hal seperti perbaikan jalan, perbaikan rumah, pembuatan saluran drainase, penghijauan, pelatihan UMKM hingga pembentukan destinasi wisata baru. Maka dari itu, pemanfaatan digital dapat memberikan pengaruh yang besar terhadap kampung tematik dengan melakukan komunikasi pemasaran yang cepat dan mudah dapat produk yang dihasilkan oleh kampung tematik mendapat perhatian besar dari khalayak. Tujuan dari program ini adalah untuk memberikan arahan tentang bagaimana mempromosikan kampung dalam memasarkan produk hasil dengan menggunakan media sosial yang baik dan benar melalui pemanfaatan Media Vlooging. Adapun manfaat dari kegiatan ini adalah untuk memberikan pemahaman dan pengetahuan kepada semua golongan terutama remaja yang merupakan bagian dari kampung tematik mengenai pemanfaatan digital dan penggunaan sosial media dengan menggunakan media Vlogging. Metode kegiatan yang dilakukan adalah dengan Presentasi, Tanya Jawab dan Praktek. Khalayak sasaran berjumlah 50 orang yang diantaranya adalah anak - anak, remaja dan orang dewasa. Kegiatan akan dilakukan di Desa Sawarnah dan Bayah, Kabupaten Lebak, Banten, dengan harapan warga sekitar dapat memanfaatkan komunikasi digital untuk memasarkan daerah wisata dengan efisien sehingga dapat membantu pengembangan daerah wisata dan meningkatkan perekonomian setempat.
\end{abstract}

Kata Kunci: Pemanfaatan Media Vlogging, Pengembangan daerah Wisata,, Sawarnah, Bayah, Kabupaten Lebak 


\section{PENDAHULUAN}

Membuat vlog di era disrupstion ini sangat penting bagi siapa saja, termasuk bagi warga desa dan kelurahan yang ingin menginformasikan kegiatan dan program-program desanya dalam bentuk video yang menarik.

Banyak kegunaan membuat blog di era kini, selain bisa memperkaya kemampuan kita di sisi yang lain kemampuan inni bisa diterapkan dalam kehidupan sehari-hari terkait dengan penyampaian pesan komunikasi.

Destinasi desa dapat menjadi bahan yang tidak ada habisnya untuk membuat Vlog. Vlog berasal dari dua kata yakni 'video' dan 'blog'. Apa itu video? Video adalah teknologi untuk menangkap, merekam, memproses, mentransmisikan dan menata ulang gambar bergerak. Lalu apa itu Blog? Blog adalah catatan pribadi secara online yang sering diperbarui dan didistribusikan ke masyarakat umum. Nah, kalau begitu apa itu Vlog? Jadi, Vlog adalah catatan pribadi dalam bentuk video yang diperbarui dan didistribusikan secara umum. Lebih lengkapnya, Vlog ini termasuk suatu bentuk kegiatan blogging dengan menggunakan medium video di atas sumber media utamanya yakni penggunaan teks atau audio

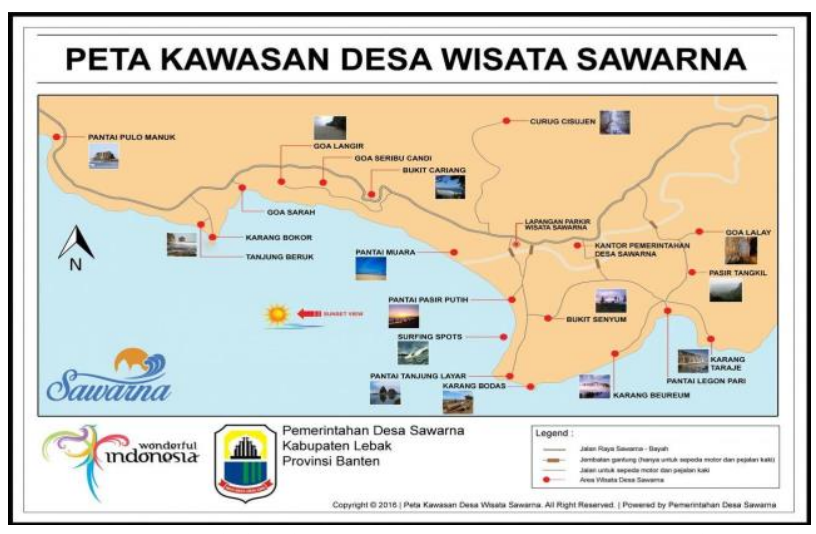

Kondisi di atas, sangat cocok sekali untuk diterapkan bagi warga Desa Sawarna dan Bayah Kabupaten Lebak untuk menggambarkan dan menyebarluaskan potensi desa wisatanya melalui berbagai media, salah satuya melalui media social. Kontur wilayah, sajian panorama, serta kulinari dan adat istiadat setempat menjadi daya Tarik untuk disampaikan kepada masyarakat luar. Dan salah satu sarana yang paling tepat dan pas untuk

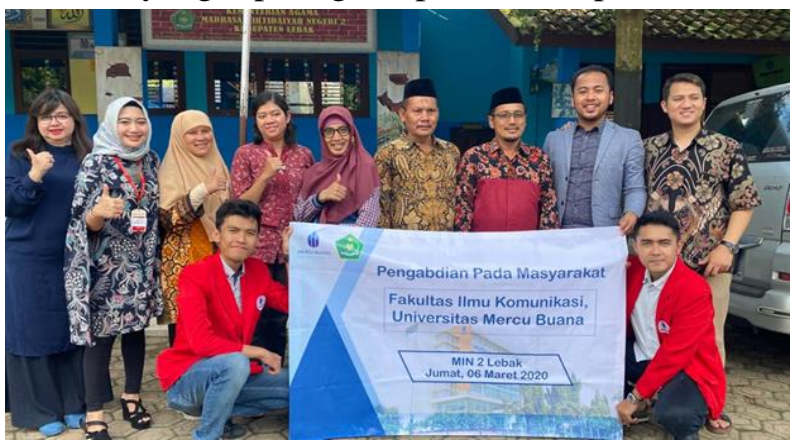

menginformasikan kepada masyarakat luar dengan menggunakan Vlog. Maka dari itu pelatihan pemanfaatan dan pembuatan vlog itu penting bagi masyarakat sasaran. Beragamnya informasi yang terkadang tidak tertata dengan baik di tengah masyarakat bisa mengganggu tatanan kemasyarakatan yang ada. Teknik pembuatan vlog ini sebenarnya alternatif bagi masyarakat di tengah perkotaan yang bisa memanfaatkan waktu dan kemampuannya untuk menciptakan video blogging yang bermanfaat bagi masyarakat. Contoh yang paling gampang adalah warga masyarakat bisa membuat vlog tentang bagaimana saat mereka memasak, membuat kue atau kegiatan lainnya yang bermanfaat buat orang lain.

Berdasarkan latar belakang dan situasi di atas, maka identifikasi masalahnya adalah sebagai berikut; "Bagaimana masyarakat desa Sawarnah dan Bayah Kabupaten memanfaatkan internet dan membuat video blogging di wilayahnya? Kegiatan ini di harapkan memberikan pemahaman yang mendalam tentang pemanfaatan dan teknik membuat vlog yang memberikan manfaat bagi warga desa Sawarnah dan Bayah Kabupaten Lebak, Banten, sehingga diharapkan manfaat yang didapat memberi dampak yang positif bagi mereka, dengan mampu membuat vlog maka desa wisata Sawarnah dan Bayah menjadi terkenal, dan mengundang wisatawan local dan manca Negara untuk datang ke daerah tersebut dan berimbas bisa menghasilkan tambahan baru bagi warga desa dan meningkatkan perekonomian warga melalui hasil pendapatan iklan yang masuk, disamping menambah kemampuan melakukan literasi informasi. 
Selain manfaat di atas, tujuan dilaksanakan pelatihan pembuatan vlog ini adalah untuk membuka wawasan/pengetahuan dan memberikan bekal kepada warga desa Sawarnah dan Bayah untuk secara kritis memanfaat kemampuan menggunakan media sosial dan pemanfaatan internet yang dapat memberikan nilai ekonomi bagi mereka dengan membuat Dengan demikian diharapkan nantinya warga desa Sawarnah dan Bayah melakuk vlog ini secara professional. Kegiatan ini di harapkan memberikan pemahaman yang mendalam tentang teknik pembuatan vlog yang memberikan manfaat bagi warga desa Sawarnah dan Bayah, Kabupaten Lebak, Banten, sehingga diharapkan manfaat yang didapat memberi dampak yang positif bagi mereka, dengan mampu membuat vlog maka di tengah keluarga bisa menghasilkan tambahan baru dari hasil pendapatan iklan yang masuk , disamping menambah kemampuan melakukan literasi informasi.

Selain manfaat di atas, tujuan dilaksanakan pelatihan pembuatan vlog ini adalah untuk membuka wawasan/pengetahuan dan memberikan bekal kepada warga desa untuk secara kritis memanfaat kemampuan menggunakan media sosial dan pemanfaatan internet yang dapat memberikan nilai ekonomi bagi mereka dengan membuat Dengan demikian diharapkan nantinya warga desa melakukan video vlog ini secara professional.

Ada pun target yang diharapkan adalah berupa pemahaman memilih media dan konten yang memberikan dampak positif bagi mereka.

\section{METODE}

Pengabdian Masyarakat ini dilakukan di Desa Sawarnah dan Kabupaten Lebak, Banten, tepatnya di Madrasah Ibtidaiyah Negeri 2 Kabupaten Lebak, Banten, dan dilakukan pada tanggal 6 Maret 2020. Mengingat peserta adalah warga desa, remaja, ibu ibu warga desa, khususnya warga desa Sawarnah dan Bayah, kebanyakan peserta adalah remaja, ibu ibu, dan bapak bapak, maka kegiatan diarahkan untuk memberikan pemberdayaan bagi peserta, bentuk yang dilakukan selain menjelaskan secara detil, juga praktek atau demonstrasi langsung dihadapan peserta, selain itu selama beberapa minggu, juga melakukan pendampingan dan monitoring untuk melihat keberhasilan pelatihan pembuatan vlog . Dalam mengatasi permasalahan yang terjadi pada masyarakat mitra sebagaimana yang telah diuraikan sebelumnya, maka dalam Program Kemitraan Masyarakat ini ditawarkan beberapa metoda pendekatan yang dapat membantu dalam menyelesaikan masalah yang ada yaitu dengan melakukan Metode Presentasi mengenai pembuatan Vlog. Untuk menjelaskan berbagai hal terkait dengan Teknik pembuatan Vlog di atas, maka pelatihan ini dilakukan dengan menggunakan metode presentasi. Penjelasannya sebagai berikut : Ceramah. Metode ini dipilih untuk menyampaikan konsep-konsep yang penting dalam menjelaskan apa itu vlog, nagaimana Teknik pembuatan vlog, memilih aplikasi video yang sesuai, memilih topik, talen , memilih pesan yang hendak disampaikan, tata editing video dan melakukan proses pasca produksi hingga menghasilkan kualitas video vlog yang sesuai dengan yang kita harapkan.Demonstrasi. Metode ini dipilih untuk menunjukkan contoh-contoh teknik pembuatan vlog, menentukan topik yang sesuai, menyajikan contoh vlog bagus yang bisa ditiru dan dimodifikasi sesuai degan kebutuhan Kemudian melakukan praktik langsung membuat vlog yang sesuai dengan kebutuhan. Latihan dan Tanya Jawab. Metode ini digunakan untuk memperjelas wawasan dan pemahaman peserta, dan meminimalisir kesalahan mempraktekkan pembuatan vlog.

\section{HASIL DAN PEMBAHASAN}

Pada tahap awal, Penyusunan program sosialiasi ini dilakukan dengan melakukan survey awal ke Desa Sawarnah dan Bayah. Program ini meliputi semua hal-hal yang bersifat teknis, manajerial dan penjadwalan (time schedule). Pembuatan bahan presentasi Presentasi ini untuk menyampaikan informasi dan pengetahuan tentang ilmu yang berkaitan dengan digitalisasi. Presentasi disertai dengan ditampilkan gambar sehingga membuat peserta lebih memahami dan menarik.

Persiapan sarana dan prasarana pelatihan. Persiapan ini meliputi penyediaan sarana dan prasarana tempat sosialisasi dan pelatihan.Koordinasi lapangan. Koordinasi lapangan 
akan dilakukan oleh Tim. Sosialisasi program Pemanfaatan Media Vlogging Untuk Pengembangan Pemasaran Desa Wisata Kabupaten Lebak (Desa Sawarnah dan Bayah), bagi masyarakat ini dilakukan dilokasi kegiatan yaitu sesuai area yang akan disepakati. Sosialisasi dilakukan sebanyak dua kali dengan bersifat informal dengan menemui kepala lurah setempat

Tahap pelaksanaan dalam kegiatan pengadian kepada masyarakat ini diantaranya adalah:Pembahasan materi mengenai teknik pembuatan Vlog,Memberikan pengetahuan tentang pembuatan teknik pembuatan Vlog dan Pelatihan pembuatan Vlog serta mengadakan sesi diskusi sebagai bentuk sharing kepada peserta untuk dapat lebih memahami konsep pembuatan Vlog

Tahap Monitoring dan Evaluasi. Monitoring dilakukan secara intensif oleh tim pelaksana setiap kegiatan berlangsung untuk memastikan agar pelaksanaan kegiatan dapat berjalan sesuai rencana. Evaluasi dilakukan sejalan dengan monitoring, sehingga jika ada kendala akan segera diselesaikan. Evaluasi dilakukan pada tahap akhir dari kegiatan, melalui pengumpulan data berdasarkan pengamatan terhadap jalannya kegiatan sosialisasi. Pada tahap presentasi, evaluasi dilakukan dengan menyimpulkan pemahaman peserta. Hasil sosialisasi diukur dengan ketepatan dan keaktifan peserta dalam berbicara satu sama lain serta dapat

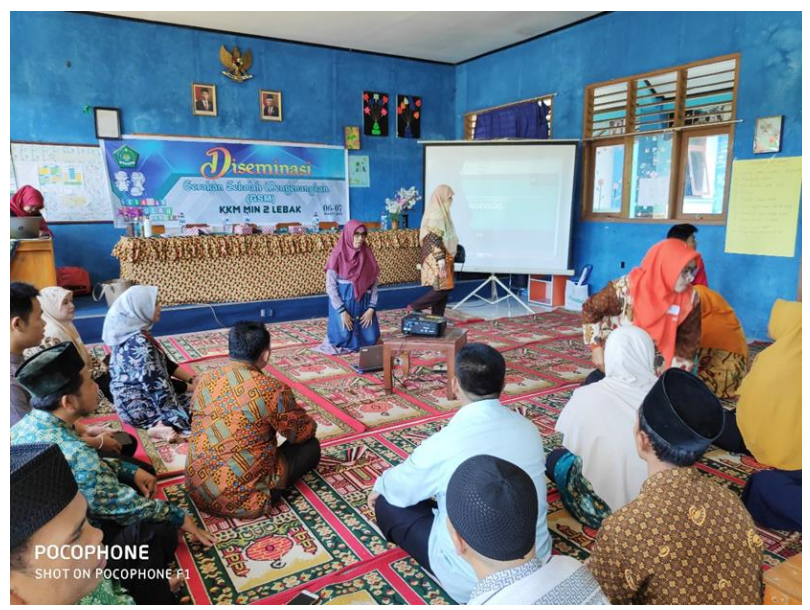

mengimplementasikan teori yang telah diterangkan.

Kegiatan Pengabdian Kepada Masyarakat dengan Sosialisasi melalui tema "Pemanfaatan
Media Vlogging Untuk Pengembangan Pemasaran Desa Wisata Kabupaten Lebak (Desa Sawarnah dan Bayah)" diadakan pada Jumat, tanggal 0 Maret 2020 Pelaksanaan Sosialisasi ini diawali dengan kegiatan registrasi peserta yang dilakukan di Aula kelas Madrasah Ibtidaiyah Negeri 2 Kabupaten Bayah. Registrasi dilakukan mulai pukul 08.00-09.00 WIB. Setelah registrasi peserta selesai dilakukan, peserta diarahkan oleh tim untuk masuk kedalam Aula kelas dan menempati tempat duduk yang telah disediakan. Kemudian, setelah semua peserta telah memasuki tempat sosialisasi dan menempati tempat duduk yang

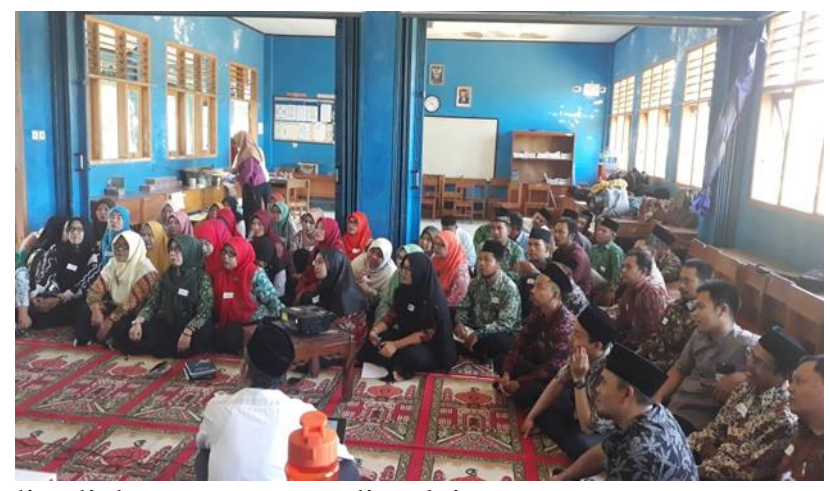

disediakan, acara pun dimulai.

Setelah itu, acara dilanjutkan dengan kata sambutan dari Kepala Sekolah Madrasah Ibtidaiyah Negeri 2 Kabupaten Lebak, Selanjutnya acara pertama adalah pemaparan materi yang dilakukan oleh pelaksana pengabdian masyarakat Fikom UMB yaitu Dr. Yoyoh Hereyah, M.Si, CPR.

Kegiatan ini di harapkan memberikan pemahaman yang mendalam tentang teknik pembuatan vlog yang memberikan manfaat bagi warga desa Sawarnah dan Bayah, Kabupaten Lebak, Banten, sehingga diharapkan manfaat yang didapat memberi dampak yang positif bagi mereka, dengan mampu membuat vlog maka di tengah keluarga bisa menghasilkan tambahan baru dari hasil pendapatan iklan yang masuk , disamping menambah kemampuan melakukan literasi informasi. Selain manfaat di atas, tujuan dilaksanakan pelatihan pembuatan vlog ini adalah untuk membuka wawasan/pengetahuan dan memberikan bekal kepada warga desa untuk secara kritis memanfaat kemampuan menggunakan media sosial dan pemanfaatan internet yang dapat memberikan nilai ekonomi bagi mereka dengan 
membuat Dengan demikian diharapkan nantinya warga desa melakukan video vlog ini secara professional.

Ada pun target yang diharapkan adalah berupa pemahaman memilih media dan konten yang memberikan dampak positif bagi mereka.

Potensi daerah wisata di desa Sawarnah dan Bayah belum dilakukan secara optimal, diperlukan upaya mempromosikan desa wisata ke wisatan local maupun manca negara, salah satu upaya yang dilakukan adalah membuat konten yang memotret tentang daerah wista yang ada di desa wisata Sawarnah dan Bayah melalui pembuatan Vlog dan memanfaatkannya untuk promosi desa tersebut.Banyak cara yang bisa dilakukan untuk mempromosikan desa wisata Sawarnah dan Bayah ini, salah satunya adalah melalui pembuatan konten media Vlogging agar dikenal public local dan manca negara.

Teknik komunikasi yang digunakan dalam kegiatan pengabdian kepada masyarakat yaitu menggunakan teknik, informatif, deskriptif dan edukasi. Pemaparan informasi yang dikemas dengan materi - materi yang bersangkutan dengan topik kelompok, memberikan informasi mengenai teknik pembuatan vlogging secara general dan spesifik, kemudian menjelaskan tips dan trik bagaimana membuat konten vlog yang menarik.

\section{KESIMPULAN}

Kegiatan Pengabdian Kepada Masyarkat "Pemanfaatan Media Vlogging Untuk Pengembangan Pemasaran Desa Wisata Kabupaten Lebak (Desa Sawarnah dan Bayah), merupakan hal terpenting dalam menjalankan pengembangan desa wisata di Kabupaten Lebak, khususnya desa wisata Sawarnah dan Bayah, namun karena kurangnya publikasi dan promosi sehingga tingkat kedatangan wisatan local dan manca negara kurang signifikan. Salah satu upaya yang dilakukan dengan membuat konten tentang desa wisata dengan memanfaatkan media vlogging sebagai sarana pembuatan konten untuk publikasi desa wisata tersebut.

Melalui pembuatan konten dengan media Vlogging, pengembangan pemasaran dan publikasi mengenai des wisata dapat terekspose ke luar. Hasil pengabdian masyarakat yang dilakukan tim Fikom UMB diharapkan dapat menghasilkan profit dan membantu ekonomi masyarakat jika pembuatan konten promosi dikelola dengan baik dan profesional.

Dari hasil observasi dan studi lapang yang dilakukan saran sebaiknya diberikan bimbingan lanjutan dengan pelatihan teknik pembuatan konten yang lebih beragam dan pendampingan bagi peserta agar pelatihan yang diberikan memberi dampak bagi pengembangan deswa wisata desa Sawarnah dan Bayah.

\section{REFERENSI}

https:// http://www.kaiamedia.com/pengertian-vlog https://en.wikipedia.org/wiki/Vlog

https://convertkit.com/how-to-vlog 